
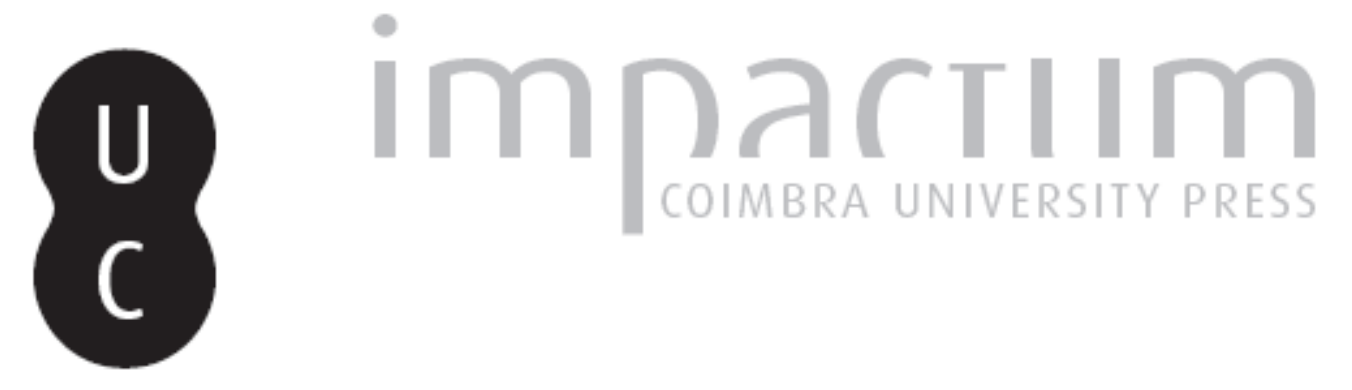

\title{
O teatro e a Universidade de Coimbra
}

Autor(es): Barata, José Oliveira

Publicado por: Imprensa da Universidade de Coimbra

URL persistente:

http://hdl.handle.net/10316.2/42889

DOI:

https://doi.org/10.14195/2183-8925_12_13

Accessed : $\quad$ 26-Apr-2023 09:05:08

A navegação consulta e descarregamento dos títulos inseridos nas Bibliotecas Digitais UC Digitalis, UC Pombalina e UC Impactum, pressupõem a aceitação plena e sem reservas dos Termos e Condições de Uso destas Bibliotecas Digitais, disponíveis em https://digitalis.uc.pt/pt-pt/termos.

Conforme exposto nos referidos Termos e Condições de Uso, o descarregamento de títulos de acesso restrito requer uma licença válida de autorização devendo o utilizador aceder ao(s) documento(s) a partir de um endereço de IP da instituição detentora da supramencionada licença.

Ao utilizador é apenas permitido o descarregamento para uso pessoal, pelo que o emprego do(s) título(s) descarregado(s) para outro fim, designadamente comercial, carece de autorização do respetivo autor ou editor da obra.

Na medida em que todas as obras da UC Digitalis se encontram protegidas pelo Código do Direito de Autor e Direitos Conexos e demais legislação aplicável, toda a cópia, parcial ou total, deste documento, nos casos em que é legalmente admitida, deverá conter ou fazer-se acompanhar por este aviso. 


\section{UNIVERSIDADE}

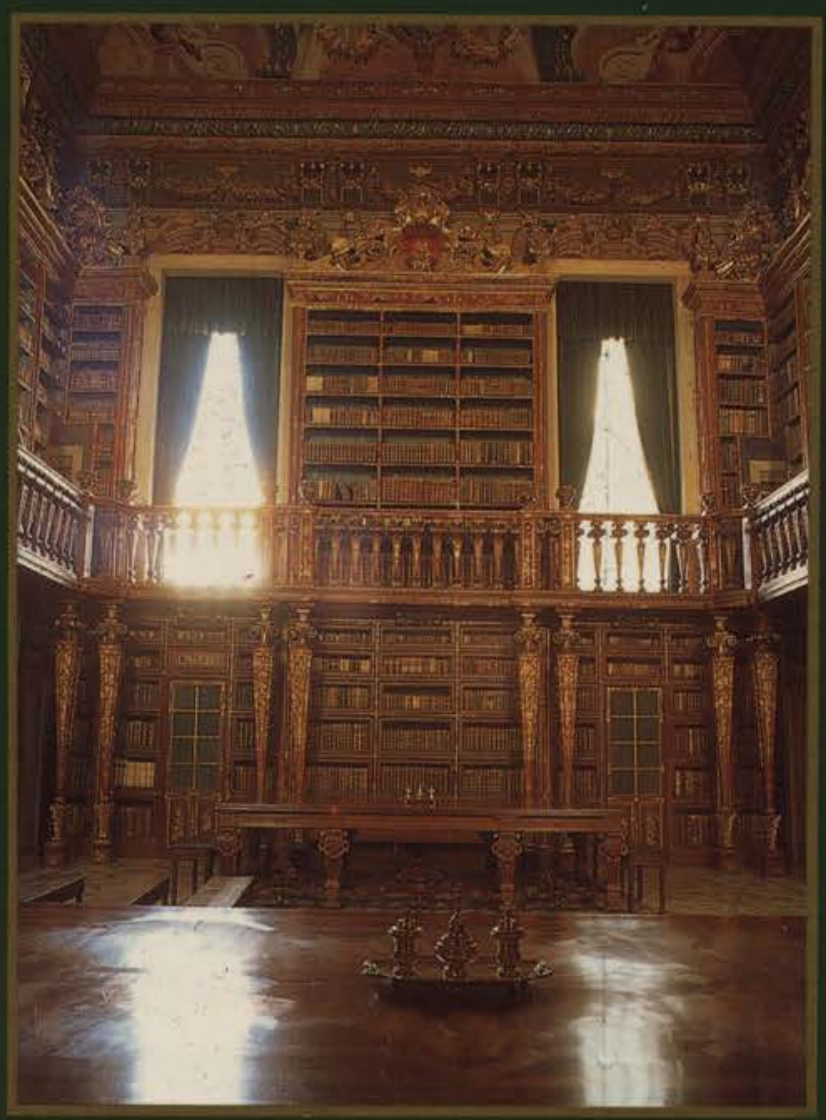

INSTITUTO DE HISTORIA E TEORIA DAS IDEIAS FACULDADE DE LETRAS 


\section{O TEATRO E A UNIVERSIDADE DE COIMBRA}

Ao contrário do que, eventualmente, possa indiciar o título escolhido para este artigo - $O$ Teatro e a Universidade de Coimbra (1) -, na indecisão cronológica que sugere a sua formulação, não se pretende chegar a conclusões definitivas.

Com efeito, a vastidão documental já explorada e a que sabemos por explorar, se, por um lado, nos confirma a urgência em se escrever um capítulo da história desta Universidade que incida, especialmente, sobre a vitalidade da actividade dramática, por outro, estimula-nos a, por entre indecisões e certezas, procurar as grandes linhas de força, que presidiram à relação do teatro com a instituição universitária e, igualmente, com a cidade em que esta se insere.

Porém, e procurando desfazer as ambiguidades, diga-se que, falar de o teatro e a Universidade de Coimbra não é exactamente o mesmo que analisar a produção teatral na Universidade de Coimbra onde, de pleno direito, cabe a história de produção teatral no espaço da Universidade, intra muros universitários, ou mesmo quando realizada fora deles, sempre hegemonizada pela sua sombra tutelar.

Nem de outra forma poderia ser, sabendo-se como se sabe, a estreita ligação que a instituição universitária mantém com a cidade.

Com efeito, sempre as manifestações citadinas acabaram por se projectar na esfera da universidade, tal como os principais momentos da

(*) Faculdade de Letras da Universidade de Coimbra.

(1) Mais não se pretende do que tecer breves reflexões tomando como base os elementos que, embora dispersos, são ainda hoje ponto de referência obrigatório para o que poderíamos antever como uma História do Teatro na Universidade de Coimbra. Seria desejável ir mais lnge. No entanto, como facilmente se adivinhará, a revelação de novos dados - neste como em outros domínios - implica uma aturada pesquisa documental que só será possível congregando vários esforços e mobilizando saberes diversos. Recuperando alguns dados que julgamos novos e revendo os preciosos contributos já existentes, a este tema esperamos voltar com mais demora e maior eloquência documental. 
festa universitária se repercutiram no espaço urbano, invadindo-o e acabando por prolongar extra muros o que, inicial e matricialmente, era apenas iniciativa académica.

Talvez por esta estreita articulação, mas igualmente pela especificidade que rege qualquer abordagem do fenómeno «teatro" - entendido na sua plenitude essencial como a projecção espectacular de um texto -, o estudo das manifestações teatrais na Universidade de Coimbra, ou qualquer reflexão sobre o teatro e a Universidade de Coimbra, solicita (quase exige), o estudo interdisciplinar, reafirmando-se, mais uma vez, o valor e importância desta atitude metodológica que, embora ciclicamente repetida como projecto de intenções, na prática, poucas vezes se tem concretizado.

Não é fácil - diríamos que é impossível - para certos períodos da história teatral que procuramos fixar, reduzirmo-nos exclusivamente à letra dos textos disponíveis ou ainda por encontrar.

Com efeito, as manifestações dramáticas predominantes no espaço académico regeram-se, na maioria das vezes, por uma densa teatralidade que em muito ultrapassou a simples ilustração cénica da palavra para se oferecer aos olhos e ouvidos dos espectadores como verdadeiras obras totais cujo sentido global requer ao estudioso de hoje, uma perfeita conjugação com os contributos fornecidos por múltiplas disciplinas.

Pode parecer que se quer particularizar, no domínio que aqui nos ocupa, um aspecto que se apresenta metodologicamente generalizado. Porém, assim não é.

A título de exemplo, veja-se como o teatro escolar dos humanistas, só será cabalmente explicado e compreendido, se se conhecer, e valorar correctamente, o papel que cabia ao teatro enquanto veículo de uma específica pedagogia, cuidando, simultaneamente, em se interrogar sobre a complementaridade significativa que assumiam tão luxuosos aparatos cénicos.

Convirá igualmente questionar-se sobre o verdadeiro significado e alcance de uma estratégia didáctica, quando as portas colegiais se abriam ao público, assim se comprovando a plena consciência dos objectivos últimos que se visavam obter junto do vulgar cidadão, deslumbrado com tanto gozo espectacular.

Estamos, pois, em presença de uma História Social do Espectáculo que, se solicita a leitura dos textos manuscritos e impressos que até nós chegaram, não pode dispensar o contributo das «várias» histórias: da história de arte à história económica e social, passando pela forte componente da história das mentalidades, não ignorando o penoso trabalho preliminar de quantos, percorrendo arquivos e bibliotecas, se encontram plenamente justificados e recompensados, quando, na aridez de muitas e «desvairadas» buscas, descobrem o documento ilumi- 
nador (sempre parcialmente iluminador!), mas sempre igualmente gratificante para quem sabe que a investigação é um permanente fazer...

Os dados que hoje podemos coligir, embora dispersos e incompletos, encontramo-los em alguns trabalhos de referência obrigatória (2).

Porém, se a variedade de dados reunidos desde logo nos coloca perante uma continuidade teatral, simultaneamente, comprova-nos a efectiva dificuldade em distinguir entre o que foram manifestações estritamente académicas e outras que, dado o seu carácter específico, por mais de uma vez, reuniram Universidade e cidade na celebração festiva, comprovando a íntima relação que ambos espaços, entre si, sempre mantiveram.

Embora não descurando a importância dos trabalhos já realizados, julgamos que se torna necessário ir mais longe.

Para além do muito que sabemos por descobrir, não se poderá ficar apenas por um seco inventário de nomes e datas.

Ter-se-á que, num maior esforço interpretativo, sistematizar periodologicamente os grandes vectores que enformaram a actividade teatral, de molde a ser claramente perceptível onde e quando, o teatro dentro da Universidade, ou na sua natural extensão citadina, acabou por ser simples prolongamento da tradição europeia ou verdadeira ruptura inovadora, assim polarizando momentos fulcrais de renovação, projectando-se no âmbito mais lato do teatro nacional.

Muito está, pois, por fazer. Talvez só uma sistemática procura no Arquivo e na Biblioteca Geral desta Universidade ( ${ }^{3}$ ) ou ainda, e decisivamente, no Arquivo da Misericórdia, nos permita ter uma noção

(2) Referimo-nos às numerosas informações que se podem recolher em estudos já publicados. Entre eles cfr. José Pinto Loureiro, O Teatro em Coimbra. Elementos para a sua História, Coimbra, Edição da Câmara Municipal, 1959; Teófilo Braga, História da Universidade de Coimbra, Lisboa, Typographia da Academia Real das Sciencias, 1898, vols. I, II e III; Claude-Henri Frèches, Le Théâtre Néo-Latin au Portugal (1550-1745), Paria-Lisbonne, Nizet-Bertrand, 1964; Jorge de Faria, «O teatro escolar dos séculos XVI, XVII e XVIII", in A Evolução e o Espírito do Teatro em Portugal, $2 .^{\circ}$ Ciclo (1. ${ }^{\mathrm{a}}$ Série) de Conferências promovidas pelo «Século», 1947, pp. 277-278; Américo da Costa Ramalho, «Um manuscrito de teatro humanístico conimbricense», in Estudos sobre a Época do Renascimento, Coimbra, Centro de Estudos Clássicos e Humanísticos, 1969, pp. 333-345; Luciana Stegagno Picchio, «Sul teatro neolatino in Portogallo», in Richerche sul Teatro Portoghese, Roma, Edizione dell'Ateneo, 1969, pp. 373-386. Para período mais recente, cfr. os contributos periódicos, saídos em o Arquivo Coimbrão ou em O Conimbricense, pela pena de Francisco Augusto Martins de Carvalho, sem esquecer a importância de trabalhos monográficos como os de António José Soares em Subsídios para a História do Teatro dos Estudantes da Universidade de Coimbra, Coimbra, TEUC, 1961.

(3) Um primeiro e importante levantamento de manuscritos latinos (onde se incluem peças teatrais) para o estudo do humanismo português, foi realizado por Américo da Costa Ramalho. Cfr. Catálogo dos Manuscritos da Biblioteca Geral da Universidade de Coimbra, Relativos à Antiguidade Clássica, Coimbra, Biblioteca Geral da Universidade, 1945. 
mais clara das atitudes escolar e citadina perante o espectáculo teatral $\mathrm{e}$, mais genericamente, perante os divertimentos públicos e privados.

Estas reflexões não surgem motivadas por qualquer necessidade de justificar o frustrante sentimento de incompletude sentido perante o pouco que podemos dizer, sabendo, à partida, que muito mais, e mais fundamentalmente, se poderia revelar, se neste domínio houvesse vontade de proceder a um sério trabalho de investigação $\left.{ }^{4}\right)$.

Mas falemos do teatro que a Universidade viu e ouviu, escreveu e leu, procurando superar a simples enumeração factual, para privilegiar os momentos fulcrais, e verdadeiramente marcantes, na evolução estética de uma experiência dramática que teve no Humanismo um dos seus momentos mais altos.

Ficariam, porém, incompletas estas breves notas se nos ficássemos exclusivamente pelo teatro institucionalizado. Será bom não perder de vista as constantes manifestações de pura teatralidade que, ciclicamente, percorreram a vida académica, desde as festas goliárdi-

(4) A recente publicação das Actas do Congresso «História da Universidade" (Cfr. Universidade(s). História. Memórias. Perspectivas. Congresso História da Universidade, $7{ }^{\circ}$ Centenário, Coimbra, 1991, 5 vols.) marcam, em nosso entender, uma das mais sólidas e importantes realizações que, produtivamente, assinalaram a passagem dos setecentos anos da Universidade de Coimbra. Julgamos, no entanto, ser ainda oportuno expressar - enquanto universitário - o nosso juízo sobre a forma como se comemorou tão importante efeméride. Das realizações já concretizadas tudo nos indicia que ainda não foi desta vez que a comunidade universitária reflectiu sobre a sua História. Tão pouco se nos afigura que, partindo dos dados que já possuímos, a Universidade se interrogue, numa perspectiva de futuro, sobre o real significado da sua identidade para, no confronto europeu, poder acrescentar aos pergaminhos da antiguidade, as singulares marcas que dela fizeram um importante pólo cultural, actuante na sua originalidade e singularidade. Só lendo o passado numa perspectiva de futuro, só comemorando com o exacto sentido de reactualizar a memória, se poderá prestigiar e honrar a história de que somos herdeiros e simultaneamente protagonistas. Para tal julgo que se impunha repensar o verdadeiro alcance e significado da presente efeméride, evitando que tivesse, por vezes, redundado numa série de iniciativas sem chama, acríticas, desconexas, podendo pensar-se que estávamos, apenas, e tão só, a cumprir um ritual comemorativista, onde tudo parecia caber, por ausência de um plano científica e pedagogicamente amadurecido... Setecentos anos de vida de uma instituição, como a nossa Universidade, não podem ser desperdiçados, diluindo a sua celebração em fugazes, banais e pouco motivadoras manifestações para coluna social ver ou Europa saber... Pareceu cumprir-se, de novo, uma pecha tão portuguesa: incapazes de gerir as nossas próprias contradições, partimos para o diálogo com os outros sempre confiantes em que, mais uma vez, funcionará a desenvoltura da pose; o brilho da raridade exposta nas vitrinas de «foruns» europeus e, paradoxalmente, quotidianamente desprezada por entre o sistemático atropelo e desleixo perante $o$ nosso património cultural. Embora não se ignorando o valor e originalidade do que se tem, parecemos pouco preocupados (e apostados) numa estratégia de afirmação solidamente apoiada no rigor planificado e na afirmação descomplexada dos nossos defeitos e virtudes. Parece ser nossa vocação confiarmo-nos ao improviso, à retórica, pontual ostentação que, na efemeridade do seu brilho, pode deslumbrar, mas é sempre uma hábil operação de charme para camuflar as nossas debilidades organizativas... 
cas às cerimónias de imposição de insígnias, testemunho eloquente das permanentes contaminações de dois universos que, longe de se excluirem, antes se completam na diversidade harmónica das realidades que reflectem.

Um estudo que talvez revelasse como certos espaços universitários, dos antigos «colégios» à Sala dos Capelos, sempre funcionaram no imaginário lúdico como locais por excelência para neles se cumprir uma estratégia do simbólico, ora ritualizado em grande proximidade do religioso, ora carnavalizado em manifestações que, por praxe ou espontaneidade colectiva, sempre se assumiram como contraponto «laico» aos ritos institucionalizados.

Todas as reflexões anteriores nos surgem com maior veemência quando, percorrendo várias fontes, nos damos conta de como seria esclarecedor para a História do Teatro Português iluminar algumas das facetas menos conhecidas do que alguns já chamaram teatro escolar - referindo-se a um arco cronológico bem preciso - e que nós, hoje, poderíamos actualizar na designação genérica de teatro universitário - tendo presente experiências nossas contemporâneas.

Jorge de Faria - cujo nome está indissoluvelmente ligado à Faculdade de Letras -, numa conferência, lida em 1946, sobre $O$ Teatro escolar dos séculos XVI, XVII e $X V I I I$, referindo-se ao hiato que, em sua opinião, se verificara no teatro escolar em Coimbra, a partir de meados do século XVIII, escrevia:

«Em Coimbra é que infelizmente a provisão de D. João III parecia letra morta. Essa tradição apenas adormecida num longo sono ressurgiu triunfantemente com o Teatro dos Estudantes da Universidade sob a direcção modelar do doutor Paulo Quintela» (5).

É evidente que muita água correu sob as pontes desde os finais do século XVIII até 1938 data da fundação do TEUC (Teatro dos Estudantes da Universidade de Coimbra).

Porém, e descontado o apressado remate do eminente bibliófilo, os grupos de teatro universitário, criados por estudantes e professores, actuando fora da alçada jurídica da Universidade, sempre foram uma constante que se pode comprovar até hoje, desde que D. João III devolveu a Universidade à cidade ( $\left.{ }^{(}\right)$.

(5) Jorge de Faria, «O teatro escolar dos séculos XVI, XVII e XVIII"...cit., pp. 277-278.

(6) A circulação das normas estatutárias entre as universidades europeias era um facto. Coimbra teve, por certo, na Universidade de Salamanca um modelo que muitos procuravam actualizar, no momento em que os estudos universitários davam os primeiros passos enquadrados no fulgor humanista. $\mathrm{O}$ teatro assumia papel particularmente relevante na estratégia pedagógica dos humanistas. Como assinala Jorge de Faria, art. cit., p. 261, a semelhança com o que, neste domínio, se passava em Salamanca era flagrante: «(...) Aires Barbosa que durante 20 anos professara latim e grego na Universidade de Salamanca, prestava ao rei esclarecimentos de tomo sobre os 
Os alvarás régios de 1546 confirmavam e davam força de lei ao que, pelo menos desde 1542 , se assumira como prática corrente.

Com efeito, a obrigatoriedade dos lentes de terceira e quarta regras de latinidade, de representar, anualmente, uma comédia, prevendo-se o estabelecimento de um subsídio pecuniário saído dos cofres da própria Universidade, em nossa opinião, visava um duplo objectivo $\left({ }^{7}\right)$.

Por um lado, procurava institucionalizar, em âmbito académico, a regularidade das representações de tragédias latinas, introduzidas pelo humanista Jorge Buchanan, e com a chancela, no plano pedagógico, do recém chegado André de Gouveia $\left.{ }^{8}\right)$.

Porém, por outro lado, é de prever que a esta decisão não tenha sido alheia a vontade de preservar a intocabilidade do reduto académico face à «imoralidade» de espectáculos goliárdicos que muito agradavam aos académicos e à população da cidade $\left({ }^{9}\right)$.

estatutos desta escola, onde os divertimentos escolares, portanto facultativos, se faziam com comédias de Plauto ou Terêncio ou com trigicomédias escritas pelos lentes». A semente germinaria também entre nós, embora nos encontremos perante as primeiras e tímidas tentativas. Cfr. José Sebastião da Silva Dias, A Política Cultural da Época de D. João III, Coimbra, Instituto de Estudos Filosóficos, 1969, vol. I, (2), p. 526: «(...) Quiseram os educadores do Mondego assimilar ainda por outra via os novos ideais escolares e culturais da Europa. A pedagogia conimbricense da época de 1535 a 1547 serviu-se já, na verdade, do teatro escolar como meio de formação humana, embora, segundo parece, timoratamente e sem continuidade».

(7) Cfr. Mário Brandão, Documentos de D. João IIII, Coimbra, Universitatis Conimbrigensis Studia Ac Regesta, vol. II, 1939. Com efeito, a 16 de Outubro de 1546 o rei publica um Alvará determinando que o Professor da Regra mais alta do Colégio de $S$. Jerónimo fizesse representar anualmente na Universidade uma comédia. Neste mesmo documento reafirmava-se o que, por alvará de 28 de Setembro do mesmo ano, ficara anunciado: «(...) que tenho mandado que os lentes da terceira \& quarta/Regras de latinidade fação \& Rpresemtem cada huũ/sua comeedia $\mathrm{E}$ ey por bem que o dito Regente leue/\& aja quimze cruzados em cada huũ Annõ pera aJuda da/ despesa da comeedia que asy ha de fazer/os quaes lhe/vos mandareis pagar no/Reçebedor das Remdas da vniver/sidade asy como mando q̃ se pague aos ditos lemtes/ da terceira \& quarta Regras. «(M. Brandão, ob. cit., pp. 69-70; o alvará de 28 de Setembro de 1546 reproduz-se a pp. $47-48$ ).

(8) Cfr. Mário Brandão, $O$ Colégio das Artes, Coimbra, Imprensa da Universidade, 1924, vol. I, p. 337: «(...) Em 1547, no ano seguinte, chegava a caravana dos Bordaleses, onde vinham talentos consumados no género, como esse Buchanan, autor de Jephtes, sive votum e de Baptistes, sive calumnia, e tradutor de grego para o latim da Medeia e da Alcestes de Eurípedes. Fundado o Colégio é fácil de imaginar o incremento que tomaram as representações. Infelizmente, que saibamos, a sorte só nos conservou memória de ter sido nele posta em scena uma tragédia, quando do bacharelato de D. António, e uma comédia ou tragédia quando da visita ao Colégio de D. João III".

(9) Idem, ob. cit., p. 336: «(...) Devemos acentuar que os divertimentos referidos (p. e. a eleição do Episcopus scholariorum) eram usanças académicas mal vistas e foram reprimidas por se não coadunarem com a ordem e disciplina. Eram quando muito tolerados. (...) A princípio as peças representadas no Colégio não passavam de sátiras, quantas vezes grosseiras e obscenas, a despeito da vigilância do principal, 
A ser assim, a Universidade - ou se se quiser os Colégios que a constituíam - passavam a dispor de autonomia dramática que, contemplando o teatro como disciplina da paideia humanística $\left({ }^{10}\right)$, simultaneamente, procurava defender os que a frequentavam do contacto com os espectáculo seculares, veiculados por companhias ambulantes, num período em que os olhares inquisitoriais, um pouco por toda a parte, se faziam bem presentes.

Coimbra e a sua Universidade afinavam pelo diapasão europeu. O exemplo que os demais colégios universitários difundiam, em toda a Europa «latinizada»; também entre nós se cumpria (11).

Com efeito, através de traduções latinas dos principais tragediógrafos e comediógrafos gregos, ou pelas sucessivas representações, no original, de poetas dramáticos latinos, assistia-se a uma permanente revitalização da matriz dramática greco-latina, quer através do exemplo prático, quer através da revalorização dos principais modelos teóricos (12).

Se "compor» comédias e tragédias, na fidelidade aos princípios pseudo-aristotélicos, era condição preferencial para o recrutamento dos professores de humanidades, de igual modo e, simultaneamente, a sua correcta execução por parte dos alunos - sobretudo enquanto arte de dizer - garantia a continuidade nos respectivos cursos (13). Poder-se-á pensar que o entusiasmo pela onda latinizante reduzia a temática da produção à esterilidade de um repertório monótono. Longe disso.

A comprová-lo surge-nos a regular produção de tragédias novila-

em que se ridicularizavam inimigos e contrários. Os abusos e desmandos que daí se seguiam tornaram o passatempo pouco simpático, principalmente a Mestres e Humanistas, que abominavam tais peças escritas e representadas por escolares incultos. Em breve o género tomava nova feição, com o triunfo dos ideais estéticos e culturais do Renascimento. $\mathrm{O}$ que fora um mero folguedo passava a ser exercício escolar de alunos, que se aperfeiçoavam no manejo da língua latina».

(10) Cfr. Álvaro Júlio da Costa Pimpão, «A literatura dramática em Portugal no século XVII", in Escritos Diversos, Coimbra, Acta Universitatis Conimbrigensis, 1972, pp. 225-238; aqui, em especial, pp. 228-230. Tb. José Sebastião da Silva Dias, $A$ Política Cultural da Época de D. João III, Coimbra, Instituto de Estudos Filosóficos, 1969 , vol. I, (2), pp. 526-527.

(11) Tudo leva a crer que o plano de estudos conimbricenses seguisse de perto o do Colégio de Guiena, donde vinha André de Gouveia. O culto da latinidade encontrava em Terêncio, no caso dos textos dramáticos, o autor mais citado. $\mathrm{O}$ plano do Colégio de Guiena encontra-se sucintamente apresentado em Álvaro Júnior da Costa Pimpão, «La introducción del humanismo en Portugal», in Escritos Diversos, cit, pp. 378-379: «(...) El programa de estudios de Coimbra no sería, em essencia, muy diferente de éste, puesto que el objectivo era el mismo. Unicamente se aprovechaba la experiencia adquirida, pero no sabemos en qué medidan.

(12) Cfr. os importantes contributos reunidos em II Teatro nel Rinascimento. A cura di Fabrizio Cruciani e Daniele Seragnoli. Bologna, Il Mulino, 1987.

(13) Cfr. José Pinto Loureiro, ob. cit., pp. 45-56. Aí se anotam muitas e preciosas informações contidas em documentos sobre a história e vida universitárias. 
tinas que, embora nuclearmente centradas e plasmadas nos modelos mais prestigiados da latinidade, se encontram recheadas de constantes alusões ao viver quotidiano local e nacional.

Nomes como Guerante, Venegas, António de Abreu ou Diogo de Teive, são os principais representantes de uma produção ainda hoje parcelarmente estudada, mas cuja importância não pode ser posta em causa (14).

Particular relevo merece, porém, o contributo de Diogo de Teive. Por vários motivos. Desde logo, porque o itinerário do conhecido hu manista é paradigmático. Ele assume-se, no período de afirmação do nosso primeiro teatro escolar, como o típico representante do humanista europeu que, após ter contactado com Salamanca, Toulouse, ter dado aulas no famoso Colégio de Guiena em Bordéus - onde conheceu André de Gouveia -, continuando a sua peregrinação por Paris, Montauban, Poitiers, chega a Portugal, acompanhado pelo escol do pensamento bordalês.

Não cabe neste espaço repetir os dados fundamentais da biografia de Diogo de Teive que, na sua singularidade e conflitualidade com o peso da tradição instituída, dele fazem uma personagem angular para uma melhor compreensão do humanismo português $\left({ }^{15}\right)$.

Interressa-nos, sim, revelar, a par do fermento inovador que até nós trouxe após múltiplos contactos europeus, como a produção dramática de Diogo de Teive nos comprova o manifesto desejo de ino-

(14) A vitalidade da tragédia no teatro português justificaria um bom estudo monográfico. Com efeito, desde o século XVI até às experiências neo-clássicas de Manoel de Figueiredo, facilmente verificamos que, embora desiguais em valor, se sucederam as tragédias originais, livremente vertidas ou simplesmente traduzidas. Aqui deixamos alguns desses exemplos: Sá de Miranda [fragmentos de Cleópatra (1520-1530); Henrique Aires Vitória (versão livre da Electra de Sófocles, seguindo de perto a tradução castelhana de Hernán Pérez de Oliva (1528), escrita em 1536 e reeditada em 1556]; Diogo de Teive (Golias, também conhecida como David, cujo texto, embora perdido, se sabe ter sido representado no mosteiro de Santa Cruz, em Coimbra, em 1550), Iohannes Princeps [escrita entre 1554 e 1558, ano em que foi editada], Judith, cujo texto se perdeu; António Ferreira [A Castro escrita e representada em Coimbra entre 1554 e 1556, sendo impressa em 1587]; Manuel Venegas [Saul Gelboeus, (1559); Achabus, (1560) Absalon, (1562)]; Simão Vieira [Saul, (1560) e De Casu Heli, (1565)]; toda a produção do Padre Luís da Cruz a que nos referiremos mais adiante; António de Abreu [Degolação de S. João Baptista (1585)]; Diogo Paiva de Andrade [Iohannes Baptista e Eduardus]; Francisco Sá de Meneses [D. Maria Teles]; António Gomes [Daniel que chegou a ser representada em Faro em 1601] e ainda Diogo Seco [Santo António (1604)]; Anselmo Xuquer [Santa Catarina (1604)]; Luís Ribeiro [Santa Maria Egipsíaca (1619)]; Frei Manuel Rodrigues [Rodericus Fatalis (1631)].

(15) Cfr. o estudo de Nair de Nazaré Castro Soares que surge como «Introdução" a Diogo de Teive, Tragédia do Príncipe João. Introdução, estabelecimento do texto, tradução e notas por Nair de Nazaré Castro Soares. Coimbra, Centro de Estudos Clássicos e Humanísticos da Universidade de Coimbra, 1977. 
var, embora solidamente ancorado na melhor tradição trágica latina, na esteira de Séneca, e na obediência aos princípios horacianos.

A Tragédia do Príncipe João (Tragoedia Ioannes Princeps) não é apenas mais uma entre as muitas tragédias latinas do século XVI já conhecidas. Como refere Costa Ramalho «ela é mais do que um exercício pedagógico para aperfeiçoamento da latinidade dos alunos e edificação moral dos participantes e audiência" (16), para preanunciar um dos tópicos mais recorrentes ao longo de toda a literatura portuguesa o tema do Sebastianismo.

Para além do mais, sabe-se como em toda a peça perpassam ecos que podemos comprovar na Castro, do lente legista António Ferreira, poeta que, juntamente com Sá de Miranda, manteve estreitos contactos com Diogo de Teive e com a actividade dramática realizada no espaço universitário.

Evocamos sumariamente estes aspectos para comprovar como a produção do teatro escolar não se pode confinar, na sua rede de influência e actuação, ao estrito espaço universitário.

A Universidade, enquanto privilegiado pólo cultural e proeminente fonte de saber, abria-se ao mundo, preocupando-se com os sucessos da história nacional. A lição bebida no exemplo dos congéneres colégios europeus, encontrava nos Paços universitários o eco actuante do primado da vida activa que, decisivamente, marca a actividade dos humanistas $\left({ }^{17}\right)$.

Por entre indecisões cronológicas, textos desaparecidos, atribuições duvidosas, o teatro escolar ganhava precisos contornos.

Regularmente representado no Colégio Real, em Santa Cruz, ou aquando das celebrações de S. Nicolau, patrono dos estudantes, ou ainda nas festividades que anualmente se organizavam para celebrar a protecção do Rei à Universidade - para nos circunscrevermos, exclusivamente, aos textos que até nós chegaram -, adivinha-se o evidente gosto pelo grande aparato cénico que, a crer nos testemunhos da época, concitava, em momentos de festividade colectivamente condividida, o interesse dos vários estratos sociais da cidade.

Particularmente importante para o estudo da actividade teatral na Universidade de Coimbra, no período humanista, é o reinado de D. João III.

Ao prestígio dos modelos apresentados nas principais obras dos autores citados, à representativa produção de António Ferreira - em Coimbra teriam sido representadas Bristos $\left({ }^{18}\right)$, eventualmente Cio-

(16) Diogo de Teive, Tragédia do Príncipe João, ant. cit., p. XI.

(17) Cfr. os trabalhos ant. cit., de Silva Dias, Costa Pimpão e Costa Ramalho.

(18) Particularmente importante é o Prólogo desta peça, nomeadamente, pela afirmação que nelle se faz quanto à influência dos exemplos humanísticos na tradição teatral portuguesa da época: «(...) Estes julguem se é vicio querer cada hum seguir com 
so; provavelmente em 1569, a sobejamente conhecida Castro (19) contrapunha-se a crescente vaga de cortejos mascarados e embuçados que eram objecto de várias proibições.

Com o teatro hierático, preferido no espaço académico, coexistia o desregramento que atingia o seu auge aquando da Procissão do Corpus Cristi.

Não por acaso surgem as constantes recomendações, como a que se pode ler nas constituições do bispado de Coimbra de 1591. Aí se recomendava que em Igrejas ou ermidas:

«(...) se não representem farsas, autos, nem comédias, ainda que sejam representações pias e históricas de santos, de dia nem de noite; nem haja nelas jogos, danças ou cantigas profanas. E aos priores, reitores e curas mandamos, sob pena de dois mil reis, que pagarão do Aljube, que não consintam que nas igrejas se façam as ditas representações, jogos ou danças, ou cantigas profanas, nem se juntem nelas leigos a cantar, dançar ou comer, ou para fazer outros actos profanos" $(20)$.

A vida teatral universitária ressentia-se de todos os vícios e virtudes que eram bem visíveis no panorama do teatro nacional.

Em Coimbra, porém, um dado não pode ser esquecido dentro do restrito quadro que nos cumpre analisar.

Referimo-nos à regular produção dramática incentivada pelos jesuítas, desde 1566 instalados no seu Colégio das Artes, na parte alta da cidade.

À semelhança do que se passará noutros centros universitários, nomeadamente em Évora, para aí se transfere o centro das atenções teatrais, como marco preanunciador do que seriam os grandes espectáculos neo-latinos marcadamente visuais e de temática celebrativo-hagiográfica.

Entendido como prolongamento da experiência humanista, dir-se-ia que nos encontramos perante uma saturação do simbólico teatral, num tempo em que, por todo o país, se começavam a pressentir as novas atitudes do homem barroco.

suas forças as cousas que bem parecem, principalmente esta, que antigamente foy tida em tanta conta, e pola qual aquelle Liuio Andronico Romão antiquissimo alcançou famoso nome pera sempre. Nom falo nos que ho segiram desde entam té agora em Italia, pois em nossos dias vemos neste reyno a honrra \& ho louvor de quem nouamente a trouue a elle, com tanta differença de todolos antigos, quanta ê a dos mesmos tempos». Cfr. Adrien Roig, La Comédie de Bristo ou L'Entremetteur (Comédia do Fanchono ou de Bristo) d'António Ferreira. Étude et analyse lexicale. Édition critique et traduction. Paris, Fondation Calouste Gulbenkian/Presses Universitaires de France, 1973, pp. 130-132.

(19) Cfr. Adrien Roig, La tragédie «Castro» D’António Ferreira. Établissement du texte des éditions de 1587 et 1598 , suivi de la traduction française. Paris, Fundação Calouste Gulbenkian/Centro Cultural Português, 1971.

(20) Apud, José Pinto Loureiro, ob. cit., pp. 55-56. 
Desta nova postura nos dá flagrante testemunho o Padre Luís da Cruz quando, no prólogo de $O$ Pródigo, escreve:

«(...) Bastante e bem conhecido foi o aplauso que lhes coube (refere-se às várias peças em latim) em certa altura, aplauso com que foram recebidas por grande multidão de universitários, de nobres e de povo, obtendo assim o louvor que lhes era devido" (21).

E, comprovando a decisiva importância da cuidada espectacularidade que se pretendia, muito para além da literariedade das mesmas, é ainda o Padre Luís da Cruz quem nos esclarece, quando afirma:

«(...) É que eu sabia que as peças que, aos olhos dos espectadores, puderam ter agradado, não iriam talvez encontrar a mesma benevolência, quando lhes viessem parar às mãos. No teatro as palavras que se dizem, voam. A ornamentação cénica dá-lhes valor, a beleza dos actores dá-lhes brilho, e a graça da representação harmoniza de tal forma o espírito com os ouvidos que se julga lindíssimo o que não deixa de ter as suas verrugas, que não se vêem, dado todo aquele artifício teatral" (22).

O teatro jesuíta impunha-se nos ambientes académicos, numa altura em que por todo o país eram bem visíveis os sintomas de uma indefinição teatral cujas causas se terão que buscar, em última análise, no complexo xadrez político cultural que se vivia.

O domínio filipino impusera decisivamente o peso dos modelos literários e dramáticos do Siglo de Oro: Calderón, Lope de Vega, Tirso de Molina); por outro lado, a progressiva presença de pintores, músicos e cenógrafos italianos trazia, até à corte portuguesa, os tímidos assomos do que viria a ser o espectáculo operístico que, associado a manifestações régias ou cerimónias litúrgicas, lenta mas seguramente, se começa a impor.

Numa esfera mais privada, facilmente identificável com a intensa vida cultural dos serões palacianos de destacados nobres da época, como o Conde de Ericeira, penetravam os ecos de um pré-«classicismo» bebido nos modelos franceses.

Nos pátios e ruas do país, à semelhança do que mais visivelmente se verificava na capital, pululavam os grupos de «companheiros de comédias" que, vagueando de terra em terra, ofereciam um repertório pouco inovador, assente, sobretudo, no testado êxito de comédias espanholas de capa e espada (23).

(21) Padre Luís da Cruz, S. J., O Pródigo. Tragicomédia Novilatina. Prefácio treslado e notas por J. Mendes de Castro. Introdução e tradução do Prólogo, por R. M. Rosado Fernandes, Lisboa, INIC - Centro de Estudos Clássicos, 1989, vol. II, p. 24.

(22) Idem, Ibidem.

(23) Cfr. José Pinto Loureiro, ob. cit., p. 57: «(...) Em 21-1-1956, os governadores do reino, em carta dirigida ao corregedor de Coimbra, informados de que ha- 
Também por essa altura Coimbra terá recebido companhias de comédias, como o atestam os poucos documentos que conhecemos.

Um deles - curiosamente protagonizado pela figura de uma mulher - encontra-se no Livro de Notas do Tabelião Francisco da Fonseca e estabelece, claramente, as cláusulas contratuais, bem como a distribuição prevista para a actuação dos vários intervenientes, cuja nacionalidade é, maioritariamente, castelhana.

«(...) no ano do nascimento de Nosso Senhor Jezus Christo de mil seiscentos e setenta e outo anos, aos nove dias do mês de Novembro do dito ano em esta cidade de Coimbra e pousadas de João Lopes (...) eu publico tabelião ao deante nomeado vim chamado estando aí partes presentes a Sarafina Manuela autora de comédias e bem assim estavam também presentes Alexandro Ordoñez e sua mulher Francisca de Bustamante e Joana Antónia e bem assim Jeronimo de Pietas e Vicente Mesia e Joan de Espanha, e Manoel de la Ensina e Francisco Rodrigues e António de Arroio todos castelhanos e representantes de comédias e assistentes nesta dita cidade e por eles (...) foi dito perante mim (...) que eles estavam contratados avindos e de acordo com a dita Sarafina Manuela pera efeito de lhe haverem de assistir na nova Companhia de Comédia que ela quer fazer (...) e que nesta forma assim se tinham contratado com ela pera efeito de lhe assistirem na dita companhia per tempo de hum ano completo..." (24).

Para além do clausulado tabeliónico, fica-nos a descrição dos papéis que cada um dos autores então "contratados» irá desempenhar, bem como ainda, a obrigação contratual da dita Sarafina Manuela ter que «dar cazas de comédias em qualquer cidade, vila, assim deste reino de Portugal como fora dele»...

Seria necessário dispor de mais dados para podermos comprovar o que, por simples dedução, aqui se generaliza, nomeadamente quanto ao estatuto social dos actores do tempo $(25)$.

via muitas inquietações e brigas causadas pelas comédias castelhanas que aqui se faziam, proibiram que tais comédias se representassem nesta cidade desde o primeiro dia de Outubro até meado de Maio, ou seja durante o ano lectivo, como agora se diria».

(24) Devemos à nossa colega Dr. ${ }^{\mathrm{a}}$ Leontina Ventura esta referência encontrada, casualmente, no decorrer das suas investigações; a A. U. C., Livro de notas do tabelião Francisco da Fonseca, n. ${ }^{\circ} 135$ (antigo 12), fls. 104-105. Para o conhecimento total do núcleo documental referente a este "contrato", cfr. José Oliveira Barata, António José da Silva. Criação e Realidade, Coimbra, Serviço de Documentação e Publicações da Universidade de Coimbra, 1985, vol. II, pp. 569-580.

(25) Cfr. Paulino Mota Tavares, «Coimbra no séc. XVII - A Praça e o Crédito», in Actas das I Jornadas do Grupo de Arqueologia e Arte do Centro, Coimbra (1979), pp. 77-89. Aqui se aduzem mais alguns elementos para o espaço concreto da cidade de Coimbra que, pelo que respeita à vigilância dos espectáculos e seus intervenientes, não fugia à regra instituída a nível nacional. Referindo-se à Praça Velha anota P. Mota Tavares: «(...) E para além de todas as proibições da Inquisição, também 
Em nossa opinião, a Universidade afirmava-se cada vez mais como trincheira de um teatro escolar que, fora da controvérsia nacional sobre a licitude das comédias, não deixava, no entanto, de exercer uma decisiva influência no teatro que, a outros níveis da sociedade barroca, se verificava.

Companhias como as de Sarafina Manuela constituíam-se como contraponto necessário e espontâneo para, num século prevalentemente teatral, responder ao gosto popular que, sempre que lhes era permitido, também acorria às manifestações universitárias.

Como se vê, encontramo-nos perante uma verdadeira coabitação. Torna-se difícil, nomeadamente desde o início do século XVII e durante todo o século XVIII, delimitar os verdadeiros círculos de acção e âmbito das representações que, dentro e fora da Universidade, se realizavam.

Sabemos que, por mais de uma vez, as autoridades municipais proibiram as representações de companhias espanholas ou, não menos significativo para uma delimitação da esfera de influências, procuravam limitar a sua apresentação, mediante o estabelecimento de um calendário temporalmente rígido (26).

Na prática, procurava-se evitar que essas companhias "profanas" não se apresentassem em Coimbra durante o decurso do ano lectivo, assim se evitando que a pax dramática universitária fosse alterada pelas buliçosas vedetas femininas, tantas vezes protagonistas de recambolescos episódios amorosos.

Por outro lado, e em estreita fidelidade às recomendações das muitas cartas directivas contra as comédias, a Universidade e os poderes municipais pareciam ter bem presente o princípio de que «o teatro ensina

as representações teatrais não faltavam nos currais da Praça, pelas noites de Verão. Segundo a letra do índice expurgatório de 1624 , caíam sob a alçada da proscrição «quaisquer Autos, Comédias, Tragédias, Farsas desonestas, ou onde entram pessoas eclesiásticas indecentemente, ou se representa algum sacramento, ou acto sacramental, ou se repreendem e vituperem as pessoas que frequentam os sacramentos e as Igrejas, ou se faz injúria a alguma ordem ou estado aprovado pela Igreja». Contudo, em 1625 foi permitido à Misericórdia «fazer curral» e sabemos que por volta de 1658 já tinham sido representados 24 entremezes, 18 em castelhano e 6 em português» [art. cit., p. 81]. Referindo-se à diversificada paisagem social que habitava na freguesia de S. Bartolomeu pode ainda ler-se no artigo citado: «(...) A estratificação profissional aponta para uma zona «sui generis" de estalajadeiros, forneiros, mercadores, saboeiros, cordoeiros, barqueiros, peleteiros e até dançadores, homens de estatuto moral especificamente duvidoso, ligados a comédias e representações teatrais a quem a própria Igreja segregava no acto ritual do enterramento». Em nota pode ler-se: "Livro de Óbitos de S. Bartolomeu (1618-1677), fl. 116. Segundo anotação do Padre Manoel Simões, a 2 de Fevereiro de 1657, os fregueses da mesma Igreja, enterraram no adro, junto aos degraus da porta principal, «a Bernardo Mendes dançador» [art. cit., p. 83].

(26) Cfr. José Pinto Loureiro, ob. cit., p. 57. 
a perversão das paixões e incita maus ensinamentos aos jovens", para se concluir que «representar comédias amatórias e ver as representações é pecado mortal» (27).

As condenações visavam, como é óbvio, todos os espectáculos que não se inserissem na linha pedagógica que se previa para o teatro enquanto eutrapélia, ou seja, na definição da época, «recreação moderada", como o eram as tragicomédias novilatinas ou as que, na elegância dos exemplos apresentados, não tinham comparação possível com as vulgares representações de anónimos comediantes.

Estas eram, citando um testemunho do tempo, «veneno bem refinado na botica da malícia humana» (28).

Porém o proibido é quase sempre o mais apetecido. Por mais de uma vez, e sempre dentro do mesmo arco temporal, sabemos que a população estudantil dificilmente se rendeu às imposições e posturas municipais, acabando, muitas vezes, por ser ela mesma, a promover espectáculos que, embora não aconselhados e fora do circuito universitário, concitavam apreço unânime.

Dentro dos colégios, a festa teatral atingia proporções inimagináveis.

O primado barroco da estesia dos sentidos, numa estética de trompe l'oeuil e onde éblouir les sens parecia um tópico obrigatório para todos os domínios da arte (não esquecendo as artes plásticas), conferia às produções, regra geral da autoria dos professores de retórica, uma adjectivação plástica que, ainda hoje, nos surpreende pela riqueza de meios técnicos (maquinaria) e plásticos (cenografia, decoração) que mobilizavam.

A "canonização de figuras da Igreja» (caso de Luíz de Gonzaga e Estasnislau Kostka), a «ilustração de passos bíblicos» ou de «dramas tragi-cómicos» bebidos na vasta literatura hagiográfica, produziram, fundamentalmente no Real Colégio das Artes, espectáculos que, hoje, não hesitaríamos em comparar a verdadeiras "superproduções" (29).

$\mathrm{O}$ reencontro proposto pelas árcades com a tradição aristotélica-horaciana, preconizando, embora, a valorização de um Teatro Novo (como sugere o título da peça de Garção), escrito em português, não enjeitava os modelos clássicos franceses, como que prolongando o fio subterrâneo do francesismo, inicialmente discreto, dos salões de alguns fidalgos organizadores de serões "académicos".

Era, no entanto, visível como os espaços se distanciavam.

(27) Cfr. José Oliveira Barata, ob. cit., pp. 307-314.

(28) Idem, Ibidem.

(29) Um dos exemplos mais expressivos que até nós chegou, data de 1727. Cfr. Relaçam/ das Festas,/ com q̃ o Collegio, \& Universidade/ da Companhia de Jesu/ da Cidade de Evora/ Applaudio e Canonização dos dous/ Gloriozos Santos/ Luis Gonzaga/ e/ Estanislau Kostka/ da mesma Companhia/ Em Novembro de 1727/ Evora, com todas as licẽças necessarias, na Officina da/ Universidade Anno de 1730//. 
Cada vez se tornava mais nítida a separação entre a esfera privada e restrita do meio universitário, e a apetência por representações semi-públicas em casas particulares ou, inclusive, incipientes teatros improvisados em casas, regra geral, sitas na rua dos Coutinhos.

Surgiram novos conflitos. Agora, que os ventos pré-românticos se faziam sentir, e à medida que a burguesia estudantil cada vez mais entra na universidade, os ideários da Revolução Francesa, para além da influência ideológica que exerciam, ajudavam a acentuar as clivagens entre o poder universitário e o poder público.

Sendo certo que nunca assistiremos a uma clara separação das respectivas esferas de influência, não é menos verdade que a semente da rebeldia se fazia sentir.

Em tempos conturbados, em que o país subitamente se vê repartido por franceses e ingleses, a contestação estudantil, particularmente vigorosa e participativa nos «movimentos liberais", vê e sente o teatro de forma completamente inovadora. E porque assim era, particularmente conflituosa com a estrutura universitária.

Em pleno domínio de Beresford, e quando os ideais liberais começavam a difundir-se, o teatro irrompe como manifestação por excelência, que a todos parecia congregar èm torno das î́deias que, ao tempo, eram já o prenúncio da abortada revolução liberal de 1817 e, da depois triunfante, em 1820.

Não surpreende pois, que entre 1813 e 1814, um grupo de quarenta estudantes procure, no seu entusiasmo militante, fundar um teatro «nos baixos do Colégio das Artes» ( ${ }^{30}$ ).

Reunido o dinheiro necessário e escolhido o repertório - essencialmente assente em tragédias clássicas traduzidas do francês (Arnaud e Voltaire) - parecia dispor-se de um local para dar làrgas aos ideais liberais, conspirar, assim cumprindo, simultaneamente, a divulgação dos ideais por que se batiam e que, artisticamente surgiam veiculados pelo género que maior aceitação tinha junto das camadas estudantis: o teatro.

Vivia-se uma situação que nada tem de novo e que se virá a repetir ao longo dos tempos.

A Universidade, fechada à sintonia com os novos tempos, confrontava-se com sucessivos pólos de contestação que escolhiam o teatro não só por este colocar em diálogo um grande número de pessoas, bem como por o teatro se apresentar como privilegiado meio de comunicação de massas, assim permitindo chegar junto de um maior número de destinatários.

A tentativa estava, porém, condenada ao fracasso. O reitor de então, D. Francisco de Lemos, privilegiado alvo das críticas estudantis,

(30) Cfr. José Pinto Loureiro, ob. cit., pp. 79-80. 


\section{Universidade}

que o mimosearam com o apelido de bispo fofo, proibiu as representações.

Continuaria, contudo, a actividade dramática; agora, porém, dispersa por várias casas privadas ou no teatro particular do Páteo de Castilhos.

Não se pode dizer que este episódio releve particularmente pela qualidade literária e dramática das peças escolhidas. Ele vale sobretudo, porque assinala um dos momentos em que a actividade dramática teve que procurar circuitos alternativos à própria Universidade. Vale, igualmente, porque neste período se inicia o percurso artístico de Garrett.

Com efeito, na sequência das experiências anteriores, e a par dos pouco conhecidos tradutores e adaptadores de obras de inspiração liberal de matriz francesa, Garrett parecia dar início a um plano que o levará a vôos mais altos. Entre 1817 e 1818 dá corpo ao Teatro da Rua dos Coutinhos ( $\left.{ }^{31}\right)$.

O jovem estudante, chegado dos Açores, apesar da sua agitada vida académica, teve ainda tempo para escrever as inéditas tragédias ao gosto neoclássico Xerxes e Lucrécia.

No entanto, o projecto parecia mais uma vez condenado a ter que se defrontar com os rigores da vigilância reitoral. Sucede-se novo interregno de seis anos.

Não esmoreceu, porém, o ânimo de quem mais parecia decidido a cumprir uma verdadeira cruzada de difusão dos novos ideais. Sucederam-se as representações em casas particulares, quer por estudantes, quer por «futricas» que, em sintonia de ideário, agora se uniam.

O teatro dos universitários, à falta de melhor, fazia-se fora do âmbito da Universidade, procurando-se, de novo, as casas e pátios particulares, como sucedeu entre 1824 e 1825 para as representações de textos de Molière (evidentemente $O$ Tartufo!), Goldoni ou a Nova Castro de João Baptista Gomes Júnior.

Em 1834, o tímido exemplo de Garrett florescia, prenúncio de uma intervenção que, como sabemos, será decisiva no panorama do teatro nacional. À estreia de Catão, sucede-se a fundação do Instituto Dramático que leva à cena obras de Mendes Leal e João de Lemos.

Como se vê, longe de se pensar que nos encontramos perante um período de nula actividade dramática, verificamos, pelo contrário, que

(31) Para um sucinto resumo da actividade do jovem Garrett enquanto «estudante-dramaturgo» cfr. Andrée Crabbé Rocha, $O$ Teatro de Garrett, Coimbra, Coimbra Editora, 1954, pp. 41-47. Para uma análise profunda e fundamentada que nos permite seguir a trajectória ideológica do autor e o seu reflexo, inclusive, nas suas primícias teatrais, cfr. Ofélia Paiva Monteiro, A Formação de Almeida Garrett, Experiência e Criação, Coimbra, Centro de Estudos Românicos, 1971, em especial, vol. I, capts. III e IV. 
o teatro foi para a intelectualidade liberal do tempo, o veículo privilegiado para a difusão de ideias, bem como, para uma activa militância política ( $\left.{ }^{32}\right)$.

Este exemplo parece ter frutificado. Passar pelo teatro fazia parte de um itinerário de vida associativa, constituindo-se em verdadeira pedagogia cívica, ou, como mais tarde afirmará Eça de Queiroz - também ele actor no Teatro Académico - uma forma de se «relacionar com o mundo".

«Comecei por me fazer actor do Teatro Académico. Era pai nobre. E durante três anos, como pai nobre, ora grave, opulento, de suiças grisalhas, ora aldeão trémulo, apoiado ao meu cajado, eu representei entre as palmas ardentes dos Académicos, toda a sorte de papéis de comédias, de dramas - tudo traduzido do francês. Por vezes, tentávamos produzir alguma coisa de mais original, de menos visto que a «Dama das Camélias», ou o "Chapéu de Palha de Itália», reunimo-nos, com papel e tinta; entre aqueles moços, nascidos em pequenas vilórias da província, novos, frescos, em todo o brilho da imaginação, uma só ideia surgiu: traduzir alguma coisa do francês» (33).

Sem entrarmos em fastidiosas listas de nomes e datas, pois não é nossa preocupação o estabelecimento de um repertório global de teatro feito na Universidade de Coimbra, tudo nos indica que, desde os finais do século XVIII, se assistia a uma sensível alteração no curso da actividade dramática.

A coexistência de teatros privados e académicos assinalava, só por si, uma ruptura com o que era prática habitual dentro da vida académica.

Se a esta nova realidade se acrescentar a turbulência da vida política portugueșa - sobretudo a partir de $1820-$, que, na luta entre tradição e inovação, mais esbateu o papel culturalmente centralizador tradicionalmente atribuído à Universidade, talvez se consiga compreender como, durante muito tempo, coexistiram representações «clássicas", quer latinas, como no caso de obras de Séneca, quer portuguesas,

(32) Cfr. Andrée Crabbé Rocha, ob. cit., pp. 41-42: «(...) [Garrett] Encontrou no entanto aí uma mocidade «agitada», assim chamada porque se movia tumultuosamente, e tinha fé na eloquência e na retórica. (...) E essa mocidade precisava urgentemente de um porta-voz, e de um lugar de onde espalhar a verdade. Como não podia ser o púlpito, seria o palco. A troco da sua disponibilidade e do seu jovem talento, dar-lhe-iam material humano e de carpintaria, por assim dizer. Actores e cenários. (...) $\mathrm{O}$ resto da Academia era-lhe útil para fazer de público. (...) Encomendavam-lhe peças de um dia para o outro, como um burguês encomenda o retrato: Garrett satisfazia as encomendas. E sacrificava assim, aparentemente sem remorsos, o que há de mais sagrado na criação, por aquilo que ela tem de mais inferior: arrebatar uma multidão. Se quis preparar-se como futuro autor de Frei Luís de Sousa, teve de o fazer por assim dizer disfarçadamente, a sós, e sem ninguém dar por isso».

(33) Eça de Queiroz, «O 'Francesismo'», in Cartas e Outros Escritos, Lisboa, «Livros do Brasil», s.d., pp. 326-327. 
como Sá de Miranda (Estrangeiros e Vilhalpandos), Camões (Anfitriões), António Ferreira (Bristo) ou Jorge Ferreira de Vasconcelos (Eufrosina)... ( ${ }^{(34)}$.

Porém o mundo movimentava-se; o xadrez ideológico mudava-se e não sem sobressalto.

Teatro e Universidade tudo isto reflectiam; não apenas a nível de repertório, mas também, e sobretudo, na mutação de gostos e espaços de representação.

Procurámos com a rapidez possível e evitando recorrer à secura de nomes, datas e títulos, traçar as principais linhas por onde evoluiu a sinuosa vida teatral na Universidade, esforçando-nos por não nos esquecermos que sempre a instituição académica reflectiu as ondas dos sismos culturais cujo epicentro, na maior parte das vezes, se situava na capital.

O surto de teatros, independentes da autoridade universitária, trará a Coimbra um maior movimento teatral, sobretudo após o romantismo. Porém, mesmo quando aparentemente o teatro rompe os muros universitários, encontramos na população estudantil e também em alguns elementos do corpo docente, em conjunção com cidadãos provindos de sociedades e núcleos corporativos bem definidos (sobretudo os que pertenciam a sociedades secretas), os principais animadores e protagonistas de uma experiência que, agora vista como necessidade cívica ao serviço da educação e mobilização da sociedade, assim prolongam o saber universitário a uma cidade universitária por excelência.

O Teatro Académico, o Teatro da Graça, a Academia Dramática, a Nova Academia Dramática, o Teatro da Sé Velha, os pequenos teatros das Sociedades de Serões Dramáticos, etc., etc., (35) são, afinal, teatros públicos animados por grupos de académicos que, alternando com a crescente vinda a Coimbra de companhias profissionais, acabaram por, progressivamente, esbater o peso do monopólio teatral que, durante séculos, a Universidade deteve e honrou com produção que não pode ser desprezada.

A «autonomia administrativa e cultural» consignada nos estatutos que regulam a actividade de grupos como o Teatro dos Estudantes da Universidade de Coimbra (TEUC) ou o Centro de Iniciação Teatral da Academia de Coimbra (CITAC), respectivamente fundados em 1938 e 1958 servem, em nosso entender, para melhor compreender o ponto de chegada de um longo percurso da experiência dramática nesta cidade.

Predominantemente, privilegiou-se o princípio da coabitação intuindo-se claramente que, se a «autonomização" perante o poder académico era desejável, a total «independência» era impossível.

(34) Andrée Crabbé Rocha, ob. cit., p. 43.

(35) Cfr. José Pinto Loureiro, ob. cit., p. 375. 
Com efeito, numa cidade em que, pela sua composição social, pelos espaços disponíveis, pelo papel nuclear que a Universidade sempre exerceu em íntima articulação com a vida da cidade, a aventura teatral estaria condenada ao fracasso se não soubesse captar o corpo académico, evitando-se enveredar por uma estratégia de confrontação.

E, mesmo quando ela existiu, foi sempre de forma pontual e episódica; nunca um decisivo braço de ferro; quase sempre momentâneas divergências de percurso, pois, a longa experiência comum aconselhava a não extremar posições.

Se, como disse Jouvet, "os homens condenados a explicar o mistério das suas vidas, inventaram o teatro", diríamos que, no caso das relações do Teatro com a Universidade, sempre a legitimação do poder universitário encontrou no teatro o seu contra-poder, paradoxalmente, legitimador porque ambos - diversa ou concorrentemente procuravam expressar no lúdico e pelo lúdico um dos mais sublimes mistérios comuns à vida de homens e comunidades: fazer do efémero uma intervenção de perenidade. 